\title{
Prověřování přímých zahraničních investic směřujících do Evropské unie
}

\author{
Mgr. Eliška Fischerová \\ Západočeská univerzita v Plzni, Fakulta právnická
}

\begin{abstract}
Anotace: Nová právní úprava obsažená v nařizení Evropského parlamentu a Rady (EU) 2019/452 ze dne 19. března 2019 stanovuje rámec pro prověřování přimých zahraničních investic ze třetích zemí do EU z důvodu bezpečnosti nebo veřejného pořádku. Příspěvek se zaměřuje na prověřovací mechanismy určené $k$ prověřování přímých zahraničních investic a jejich možnou podobu v České republice podle návrhu zákona o prověřování zahraničních investic.
\end{abstract}

Klíčová slova: prověřování zahraničních investic, přímé zahraniční investice, společná obchodní politika, veřejný pořádek

Abstract: The new legal regulation included in the regulation (EU) 2019/452 of the European Parliament and of the Council of 19 March 2019 establishes a framework for the screening of foreign direct investments from the third countries into the Union on the ground of security or public order. The paper focuses on the screening mechanisms designed for the screening of the foreign direct investments and their 
possible form according to the draft of the Foreign Investment Screening Act.

Keywords: screening of foreign investments, direct foreign investments, common commercial policy, public order

\section{Úvod}

Dne 10. 4. 2019 vstoupil v platnost nový právní rámec Evropské unie (dále jen „EU“) pro prověřování investic, a to nařizení Evropského parlamentu a Rady (EU) 2019/452 ze dne 19. března 2019, kterým se stanoví rámec pro prověřování přímých zahraničních investic směřujících do Unie (dále jen „nařizeni“). Uvedené nařizení má zásadní význam pro ochranu bezpečnosti a veřejného pořádku EU a současně stanoví členským státům řadu nových povinností.

\section{Př́ímé zahraniční investice a EU}

\subsection{Společná obchodní politika}

Zásadní přelom ve vztahu práva EU a mezinárodního investičního práva přinesla Lisabonská smlouva, v jejímž důsledku došlo k rozšíření společné obchodní politiky. Společná obchodní politika je nejrozvinutější ze všech vnějších politik EU a tvoři jádro vnějších vztahů EU. ${ }^{1}$ Podle čl. 206 SFEU platí, že „Vytvořením celní unie $v$ souladu s články 28 až 32 přispívá Unie ve společném zájmu $k$ harmonickému rozvoji světového

${ }^{1}$ FECÁK, Tomáš. Mezinárodni dohody o ochraně investic a právo Evropské unie. Praha: Wolters Kluwer, 2015, s. 148. 
obchodu, $k$ postupnému odstranění omezení mezinárodního obchodu a prímých zahraničních investic a ke snižování celních a jiných překážek“. Na citovaný článek navazuje čl. 207 SFEU, který stanoví, že se společná obchodní politika zakládá na jednotných zásadách, zejména pokud jde o úpravy celních sazeb, uzavírání celních a obchodních dohod týkajících se obchodu zbožím a službami, obchodní aspekty duševního vlastnictví, přímé zahraniční investice, sjednocování liberalizačních opatření, vývozní politiku a opatření na ochranu obchodu, jako jsou opatření pro připad dumpingu a subvencování.

Pojem přímých zahraničních investic však není v SFEU definován. V tomto ohledu se vychází z klasifikace, která je uvedena v príloze směrnice Rady 88/361/EHS, na niž konstantně odkazuje Soudní dvůr EU. ${ }^{2}$ Uvedená směrnice mezi přímé investice řadí: (i) zakládání a rozšiřování poboček nebo nových podniků patřicích pouze osobě, která poskytla kapitál, a kupování plné účasti v již existujících podnicích, (ii) účast v nových nebo stávajících podnicích s cílem vytvořit nebo udržet dlouhodobé hospodářské vztahy, (iii) dlouhodobé půjčování finančních prostředků s cílem vytvořit nebo udržet dlouhodobé hospodářské vztahy, (iv) zpětné investování zisků s cílem udržet dlouhodobé hospodářské vztahy.

Ohledně pravomoci, kterou ve vztahu k přimým investicím EU disponuje, čl. 3 odst. 1 SFEU stanoví, že se jedná o pravomoc výlučnou. $V$ této oblasti je to pouze EU, která může vytvářet a přijímat právně závazné akty a členské státy tak mohou činit pouze tehdy, jsou-li k tomu EU zmocněny nebo provádějí-li

${ }^{2}$ Tamtéž, s. 186. 
akty EU. Z čl. 3 odst. 2 SFEU dále vyplývá, že v oblastech, kde EU disponuje výlučnou pravomocí, je EU oprávněna uzavřít mezinárodní smlouvu, pokud je jeji uzavření stanoveno legislativním aktem EU nebo je nezbytné k tomu, aby EU mohla vykonávat svou vnitřni pravomoc, nebo pokud její uzavření může ovlivnit společná pravidla či změnit jejich působnost.

Změny, které s sebou přinesla Lisabonská smlouva, jsou zcela zásadní; společná obchodní politika byla rozšířena o přímé zahraniční investice a členské státy $v$ této oblasti již nemohou samostatně přijímat závazné právní akty, nebở dotčená oblast je výlučně svěřena EU.

V roce 2017 dosáhly přímé zahraniční investice $v$ EU 6,295 miliardy EUR a současně představovaly pro Evropany 16 miliónů pracovních míst. Jsou prínosem nejenom pro EU, ale rovněž i pro zbytek světa. ${ }^{3}$ Tradiční investoři (USA, Kanada, Švýcarsko, Norsko, Japonsko a Austrálie) i nadále představují nejvýznamnější investory, ale současně dochází k prudkému nárůstu investic ze strany rozvíjejících se ekonomik (např. Číny v odvětví výroby letadel a Indie ve farmaceutickém průmyslu). Dále dochází ke vzestupu prítomnosti tzv. offshorových investorů, kteří kontroluji $11 \%$ společností v zahraničním vlastnictví v EU. ${ }^{4}$

Evropská komise (dále jen „Komise“) konstatovala, že se v poslední době ozývaji obavy ohledně zahraničních investorů,

${ }^{3}$ Evropská komise. Tisková zpráva: Vstupuje v platnost nařízení EU o prověřování zahraničních investic [online]. 10. 4. 2019 [cit. 2019-07-27]. Dostupné z: <europa.eu/ rapid/press-release_IP-19-2088_cs.pdf >

${ }^{4}$ Commission Staff Working Document on Foreign Direct Investment in the EU 13. 3. 2019 (SWD (2019) 108), p. 1. 
zejména státem vlastněných podniků, kteří v rámci svých strategických plánů přebíraji evropské společnosti s klíčovými technologiemi. ${ }^{5} \mathrm{~V}$ tomto ohledu bylo zdůrazněno, že je třeba, aby EU zůstala vůči přímým zahraničním investicím otevřená, ale současně musí být doprovázena ráznými a účinnými politikami, aby „se na jednu stranu otevřely jiné ekonomiky a bylo zajištěno, že každý bude hrát podle stejných pravidel, a na druhou stranu aby byla kritická evropská aktiva chráněna před investicemi, které by mohly být nebezpečné pro oprávněné zájmy Unie nebo jejích členských států“. 6

S ohledem na shora uvedené byla zpochybněna schopnost stávajícího regulačního rámce reagovat a řešit předestřený problém a současně Komise a členské státy byly vyzvány, aby „vyhodnocovaly zahraniční investice ze třetích zemí do strategických průmyslových odvětví, infrastruktury a klíčových technologií budoucnosti nebo do jiných aktiv, která jsou důležitá z hlediska bezpečnosti a zajištění toho, aby byla prístupná“"7

V současné době téměř polovina členských států EU disponuje mechanismy pro prověřování prímých zahraničních investic, avšak doposud neexistuje systematická spolupráce

\footnotetext{
${ }^{5}$ Evropská komise. Diskusní dokument o využití potenciálu globalizace [online]. 10. 5. 2017 [cit. 2019-07-27]. Dostupné z: <https://ec.europa.eu/commission/sites/beta -political/files/reflection-paper-globalisation_cs.pdf>

${ }^{6}$ Návrh nařizeni Evropského parlamentu a Rady, kterým se stanoví rámec pro prověřováni př́mých zahraničních investic do Evropské unie [online]. 13. 9. 2017 [cit. 201907-27]. Dostupné $z$ <https://eur-lex.europa.eu/legal-content/CS/ALL/?uri=CELEX\%3A 52017PC0487>

${ }^{7}$ Usnesení Evropského parlamentu ze dne 5. července 2017 o vypracování ambiciózní průmyslové strategie EU jako strategické prioritě pro růst, zaměstnanost a inovace v Evropě (2017/2732(RSP)).
} 
mezi členskými státy a celoevropský jednotný přístup v této oblasti. ${ }^{8}$

V návaznosti na shora uvedené byla vytvořena nová celoevropská regulace, která sleduje tyto cíle:

- vytvořit ucelený rámec pro prověřování přímých zahraničních investic z důvodu ochrany bezpečnosti nebo veřejného pořádku,

- usnadnit úzkou a systematickou spolupráci mezi členskými státy navzájem a mezi členskými státy a Komisí (včetně posílené výměny informací),

- zvýšit transparentnost př́mých zahraničních investic,

- omezit obcházení vnitrostátních mechanismů prověřování přimých zahraničních investic. ${ }^{9}$

\section{Nařízení}

V souladu se shora popsanými cíli nařizení stanoví (i) rámec pro prověřování prímých zahraničních investic směřujících do EU členskými státy $z$ důvodu bezpečnosti nebo veřejného pořádku a pro mechanismus spolupráce mezi členskými státy navzájem, jakož i mezi členskými státy a Komisí, pokud jde o prímé zahraniční investice, které mohou mít vliv na bezpečnost nebo veřejný pořádek, a dále (ii) možnost, aby Komise k takovým investicím vydávala stanoviska.

${ }^{8}$ Sdělení Komise: Vstřícnost vůči přimým zahraničním investicím a současná ochrana základních zájmů ze dne 19. 9. 2017.

${ }^{9}$ Tamtéž. 
Působnost nařízení je omezena výlučně na přímé zahraniční investice. Pro účely nařizení se prrímou zahraniční investicí rozumí „investice jakékoli povahy, kterou provádí zahraniční investor a která slouží $k$ tomu, aby vytvořila nebo udržela dlouhodobé a prímé vztahy mezi zahraničním investorem a podnikatelem nebo podnikem, kterému je kapitál poskytnut za účelem výkonu hospodářské činnosti v členském státě, včetně investic, které umožňují skutečnou účast na rízení nebo kontrole společnosti vykonávající hospodářskou činnost". ${ }^{10} \mathrm{Z}$ uvedené definice vyplývá, že se bude jednat o širokou škálu investic, které vytvářejí nebo udržují dlouhodobé vztahy mezi investory z třetích zemí (včetně státních subjektů) a podniky, které vykonávaji hospodářskou činnost $v$ některém $z$ členských států. $V$ tomto ohledu Ize mít za to, že uvedená formulace bude ještě předmětem intenzivního výkladu a nařizení se bude vztahovat na řadu transakci. ${ }^{11}$

\subsection{Prověřovací mechanismy}

Zásadní význam pro uvedenou oblast maji mechanismy určené $\mathrm{k}$ prověřování přímých zahraničních investic, které ve smyslu nařízení zahrnuji nástroje s obecnou působností (jako je zákon nebo nařizení), související správní požadavky, prováděcí pravidla či pokyny stanovující podmínky a postupy pro posuzování, šetření, povolení, podmínění, zákaz nebo zrušení přimých zahraničních investic z důvodu bezpečnosti

\footnotetext{
${ }^{10}$ Dle čl. 2 odst. 1 nařizení.

${ }^{11} \mathrm{~K}$ tomu bliže HODER, Lukáš. Nové nařizeni EU o prověřování zahraničních investic nabylo platnosti. In: epravo.cz [online]. 30. 5. 2019 [cit. 2019-07-27]. Dostupné z: <https://www.epravo.cz/top/clanky/nove-narizeni-eu-o-proverovani-zahranicnich -investic-nabylo-platnosti-109430.html>
} 
nebo veřejného pořádku. ${ }^{12}$ Ve vztahu $\mathrm{k}$ prověřovacím mechanismům nařizení stanoví, že je členské státy mohou na svém území mít zavedeny, mohou je měnit nebo zavést. Konečné rozhodnutí o tom, zda zavést prověřovací mechanismus (či prověřit konkrétní zahraniční investici), bude však záviset na konkrétním členském státu.

Rozhodne-li se členský stát pro zavedení prověřovacího mechanismu, musí jeho postupy a pravidla odpovídat požadavku transparentnosti a nesměji vést $k$ diskriminaci mezi třetími zeměmi. Dále je nezbytné, aby členský stát stanovil okolnosti, na jejichž základě se prověřování zahájí, důvody pro prověřování a podrobná procesní pravidla, jimiž se bude tento postup řídit, a umožnil podat zahraničním investorům a dotčeným podnikům opravný prostředek proti rozhodnutí vydanému v rámci prověřovacího mechanismu.

\section{Faktory}

Při vytváření prověřovacích mechanismů mají zásadní význam faktory, na jejichž základě Ize učinit závěr o tom, zda přímá zahraniční investice může mít vliv na bezpečnost nebo veřejný pořádek. Nařizení obsahuje demonstrativní seznam faktorů, které mohou členské státy a Komise při posuzování investice zohlednit. Při prověřování je možné zohlednit potenciální dopady mimo jiné na:

a) „kritickou infrastrukturu, at fyzickou, či virtuální, včetně infrastruktury energetické, dopravní, vodohospodářské, zdravotnické, komunikační, infrastruktury

${ }^{12}$ Dle čl. 2 odst. 4 nařizení. 
v oblasti sdělovacích prostředků, zpracovávání nebo uchovávání údajů, infrastruktury letecké a kosmické, obranné, volební nebo finanční infrastruktury a citlivých zařízení, jakož i na pozemky a nemovitosti, jež jsou pro využivání takové infrastruktury zásadni;

b) kritické technologie a zboží dvojího užití ve smyslu čl. 2 bodu 1 nařízení Rady (ES) č. 428/2009, včetně technologií v oblasti umělé inteligence, robotiky, polovodičů, kybernetické bezpečnosti, leteckých a kosmických technologií, obranných technologií, technologií v oblasti skladování energie, kvantových a jaderných technologií, jakož i nanotechnologií a biotechnologii;

c) dodávky kritických vstupů, včetně energie nebo surovin, jakož i potravinového zabezpečení;

d) přístup $k$ citlivým informacím včetně osobních údajů nebo na schopnost kontrolovat tyto informace nebo

e) svobodu a pluralitu sdělovacích prostředků."13

Vedle shora uvedených faktorů mohou členské státy a Komise vzít v úvahu zejména:

a) „zda je daný zahraniční investor přímo či neprímo ovládán vládou třetí země, včetně státních subjektů nebo ozbrojených sil, a to i prostrednictvím vlastnické struktury nebo významného financováni;

b) zda již byl daný zahraniční investor zapojen do činností ovlivňujících bezpečnost nebo veřejný pořádek $v$ některém členském státě nebo

$\overline{{ }^{13} \text { Čl. } 4 \text { odst. } 1 \text { nařizení. }}$ 
c) zda existuje vážné riziko, že je daný zahraniční investor zapojen do protiprávní nebo trestné činnosti. “14

Pro zajištění efektivního systému spolupráce v oblasti prověřování přímých investic je nezbytné poskytování informací a koordinace mezi členskými státy a Komisí. Za tímto účelem nařizení stanoví dva speciální režimy, a to mechanismy spolupráce $v$ souvislosti s prověřovanými přímými zahraničními investicemi a mechanismy spolupráce v souvislosti s neprověřovanými přimými zahraničními investicemi.

\section{Mechanismus spolupráce $v$ souvislosti s prověřovanými přímými zahraničními investicemi}

Rozhodne-li se stát prověřit přímou zahraniční investici, je povinen tuto skutečnost oznámit ostatním členským státům a Komisi. Rozsah požadovaných informací je dán čl. 9 odst. 2 nařizení. V případě, že se jiný členský stát domnivá, že přímá zahraniční investice prověřovaná $v$ jiném členském státě může mít vliv na jeho bezpečnost nebo veřejný pořádek, nebo $v$ prípadě, kdy disponuje informacemi relevantními pro toto prověřování, může členskému státu poskytnout připomínky. Komise je oprávněna ohledně prověřované přímé investice vydat své stanovisko. Obdrží-li stát prověřujici přimou zahraniční investici stanovisko nebo připomínky, je povinen je $v$ rámci prověřování zohlednit. Konečné rozhodnutí ve vztahu k prověřované investici však zůstává ve výlučné pravomoci dotčeného členského státu.

$\overline{{ }^{14} \text { Čl. } 4 \text { odst. } 2 \text { nařizení. }}$ 


\section{Mechanismus spolupráce $v$ souvislosti s neprověřovanými přímými zahraničními investicemi}

V případě, kdy se členský stát domnívá, že přímá zahraniční investice plánovaná nebo dokončená v jiném členském státě, která není v daném členském státě prověřována, může mít vliv na jeho bezpečnost nebo veřejný pořádek, nebo disponuje ohledně dotčené přímé zahraniční investice relevantními informacemi, je oprávněn jinému členskému státu poskytnout připomínky. Za obdobných podmínek může Komise vydat ve vztahu $k$ neprověřované přímé zahraniční investici své stanovisko. Jak Komise, tak ostatní členské státy mohou požádat členský stát, $v$ němž je přímá zahraniční investice plánována nebo byla dokončena, o informace dle čl. 9 nařízení. Obdrží-li členský stát připomínky ostatních členských států nebo stanovisko Komise, je povinen je zohlednit, avšak rozhodnutí ohledně jakéhokoli opatření ve vztahu k neprověřované přimé zahraniční investici náleži výlučně dotčenému členskému státu.

\subsection{Poskytované informace}

V prípadě realizace uvedených mechanismů spolupráce je zásadní rozsah informací, které členské státy poskytují v rámci svého oznámení nebo o které jsou naopak žádány Komisí nebo jinými členskými státy.

Dle čl. 9 odst. 2 nařízení informace, které mají členské státy poskytovat, zahrnuji: 
a) „vlastnickou strukturu zahraničního investora a podniku, v němž je prímá zahraniční investice plánována nebo byla dokončena, včetně informací o konečném investorovi a podílu na kapitálu;

b) přibližnou hodnotu prímé zahraniční investice;

c) výrobky, služby a podnikatelskou činnost zahraničního investora a podniku, v němž je prímá zahraniční investice plánována nebo byla dokončena;

d) členské státy, ve kterých zahraniční investor a podnik, $v$ němž je př́má zahraniční investice plánována nebo byla dokončena, vykonávají relevantní podnikatelskou činnost;

e) financování investice a jeho zdroj, a to na základě nejlepších informací, které má členský stát k dispozici;

f) datum plánovaného dokončení přímé zahraniční investice nebo datum, kdy byla tato investice dokončena.“

V případě, že se členskému státu i přes veškeré úsilí nepodaří získat shora uvedené informace, je povinen o tomto bezodkladně zpravit Komisi a ostatní členské státy a následně ve svém oznámení náležitě zdůvodnit, proč požadované informace neposkytl, a popsat, jaké úsilí vynaložil na jejich získání.

\subsection{Další kroky}

Přestože se nařizení použivá od 11. 10. 2020, členské státy a Komise byly povinny již s nabytím jeho platnosti provést řadu kroků, které přispěly $\mathrm{k}$ tomu, aby mohlo být nařizení v budoucnosti účinně realizováno. Nařizení uložilo členským státům do 10. 5. 2019 oznámit Komisi své stávající 
prověřovací mechanismy. $V$ návaznosti na tato oznámení měla Komise do 3 měsíců od jejich obdržení zveřejnit seznam prověřovacích mechanismů členských států.

Do 31. 3. každého roku budou členské státy předkládat Komisi výroční zprávu za předchozí kalendářní rok, jejímž obsahem budou souhrnné informace o prímých zahraničních investicích uskutečněných na jejich území, a dále souhrnné informace o žádostech obdržených od jiných členských států (podle čl. 6 odst. 6 a čl. 7 odst. 5 nařízení). Rozhodne-li se členský stát zavést vlastní prověřovací mechanismus, bude povinen poskytovat každoročně také informace o tomto mechanismu.

Každý členský stát je povinen zřídit tzv. kontaktní místo, které bude zapojeno do všech otázek souvisejících s prováděním nařizení a jehož prostřednictvím budou mezi členskými státy a Komisí sdělovány potřebné informace.

\section{3 Česká republika}

Prověřovací mechanismus má zavedený téměř polovina členských států. Konkrétně se jedná o Dánsko, Finsko, Francii, Litvu, Lotyšsko, Itálii, Německo, Polsko, Portugalsko, Rakousko, Spojené království a Španělsko. ${ }^{15}$ Podoba prověřovacích mechanismů se však v rámci uvedených států liší. Jelikož v České republice obdobný prověřovací mechanismus absentuje, byl připraven návrh zákona o prověřování

${ }^{15}$ Sděleni Komise: Vstřícnost vůči přimým zahraničnim investicím a současná ochrana základních zájmů ze dne 19. 9. 2017. 
zahraničních investic (dále jen „návrh“). Předložený návrh definuje zahraniční investici velice široce, a to jako investici „jakékoli povahy uskutečňovanou zahraničním investorem, která slouži k tomu, aby vytvořila nebo udržela dlouhodobé a prímé vztahy mezi zahraničním investorem a podnikatelem nebo podnikem, kterému je nebo má být kapitál poskytnut za účelem výkonu hospodářské činnosti v České republice, a která umožňuje zahraničnímu investorovi vykonávat účinný vliv na řizení podnikatelského subjektu nebo získat přistup k informacím, systémům nebo technologiím, které jsou důležité z hlediska ochrany bezpečnosti České republiky a jejího vnitřního pořádku“.

Dle návrhu je zahraniční investor osoba, která uskutečnila nebo zamýšli uskutečnit investici v České republice a která není občanem členského státu Evropské unie, jde-li o fyzickou osobu. Definice zahraničního investora - právnické osoby - je pojata tak, ${ }^{16}$ aby zahrnula jak investory ze třetích zemí, tak unijní investory, kteři jsou ovládáni právnickou osobou či jiným právním uspořádáním ze třetí země, aby byly veškeré rizikové či potenciálně rizikové investice skutečně podchyceny.

\footnotetext{
${ }^{16}$ Dle ustanovení § 2 písm. b) návrhu se pro účely připravovaného zákona zahraničním investorem rozumí „osoba, která uskutečnila nebo zamýšlí uskutečnit investici v České republice a která není občanem členského státu Evropské unie, jde-li o fyzickou osobu, nebo která nemá sídlo v členském státě Evropské unie, jde-li o právnickou osobu. Za zahraničniho investora je považována rovněž právnická osoba, která má sídlo $v$ členském státě Evropské unie a 1. v niž může uplatňovat př́mo či nepřimo rozhodující vliv fyzická osoba, která neni občanem členského státu Evropské unie, 2. v niž může uplatňovat přímo či nepřimo rozhodujici vliv právnická osoba, která nemá sídlo v členském státě Evropské unie, 3. v níž je uplatňován rozhodující vliv prostřednictvím jiného právniho uspořádání bez právní osobnosti, zřizeného podle práva státu, který není členským státem Evropské unie, nebo 4. jejiž činnost je fakticky vykonávána mimo územi Evropské unie; za zahraničniho investora se považuje také jiné právní uspořádáni bez právní osobnosti, zřizené podle práva státu, který není členským státem Evropské unie, které uskutečnilo nebo zamýšli uskutečnit investici v České republice“.
} 
Jako orgán přislušný $k$ prověřování zahraničních investic a k rozhodování o povolení zahraniční investice bylo určeno Ministerstvo průmyslu a obchodu (dále jen „ministerstvo“), které bude současně plnit funkci kontaktního místa ve smyslu čl. 11 nařízení.

Návrh rozlišuje zahraniční investice, které vyžadují povolení vždy, a dále zahraniční investice s možností prověření z moci úřední. V prvním prípadě bude zahraniční investor povinen podat žádost o povolení zahraniční investice směřující do podnikatelského subjektu, který provádí činnosti stanovené návrhem (např. provádí výrobu, výzkum, vývoj, inovace nebo zajištování životního cyklu vojenského materiálu uvedeného ve Společném vojenském seznamu EU nebo v nařizení vlády nebo provozuje prvek kritické infrastruktury určený příslušným státním orgánem nebo je správcem informačního systému kritické informační infrastruktury). Nebude-li povolení uděleno, nesmí být zahraniční investice uskutečněna.

Ve druhém případě může ministerstvo prověřit zahraniční investici způsobilou ohrozit bezpečnost České republiky nebo její vnitřní pořádek na základě výsledku konzultace, kterou navrhl zahraniční investor. Nepředloží-li zahraniční investor návrh na konzultaci, je ministerstvo oprávněno zahájit řizení o prověření dotčené investice ex officio kdykoli, avšak nejpozději do 5 let ode dne jejího dokončení.

Návrh dále obsahuje demonstrativní výčet skutečností, které maji být zohledněny při hodnocení, zda je zahraniční investice způsobilá ohrozit bezpečnost České republiky nebo její vnitřní pořádek. Vedle faktorů, které převážně odpovídají 
faktorům v čl. 4 odst. 1. nařízení, návrh tento výčet rozšiřuje např. o nevojenské objekty důležité pro obranu státu nebo další technologie, jejichž zneužití by mohlo ohrozit bezpečnost České republiky nebo její vnitřní pořádek.

V případě, že nebude zjištěno, že zahraniční investice představuje ohrožení bezpečnosti nebo vnitřního pořádku, ministerstvo rozhodne o jejím povolení. Ministerstvo příslušné rozhodnutí vydá do 40 kalendářních dnů od dne zahájení konzultace nebo do 90 (nejpozději do 120) kalendářních dnů od zahájení řizení pro prověření zahraniční investice.

Naopak v situaci, kdy zahraniční investice bude představovat ohrožení bezpečnosti nebo vnitřního pořádku, rozhoduje o dalším postupu vláda, která může rozhodnout o podmíněném povolení nebo neudělení povolení nebo zrušení zahraniční investice. Rozhodne-li vláda o zrušení zahraniční investice, nelze proti tomuto rozhodnutí podat rozklad.

\section{Závěr}

Nařizení představuje novou regulaci, jejímž cílem je vytvořit ucelený právní rámec určený k prověřování přímých zahraničních investic z důvodu ochrany bezpečnosti nebo veřejného pořádku a usnadnit kooperaci mezi členskými státy navzájem a současně mezi Komisí a členskými státy v této oblasti. Klíčovou úlohu sehrávají prověřovací mechanismy jakožto nástroje určené $k$ prověření dotčené přímé zahraniční investice, přičemž rozhodnutí, zda je členské státy zavedou, závisí výlučně na nich. Stejně tak zůstává ve výlučné 
pravomoci členských států konečné rozhodnutí ohledně jakékoliv prověřované přímé zahraniční investice nebo jakéhokoliv opatření ve vztahu k přímé zahraniční investici, která není prověřována. Za účelem posílení spolupráce $v$ této oblasti ukládá nařízení všem členským státům povinnost každoročně předkládat Komisi výroční zprávy obsahující souhrnné informace o přimých zahraničních investicích a zřídit tzv. kontaktní místo.

V České republice byl zatím připraven návrh zákona, který má adaptovat nařízení do národního práva. Oproti nařízení návrh považuje za zahraničního investora i právnickou osobu, která má sídlo v členském státě EU, jsou-li splněny další podmínky stanovené návrhem. Ministerstvo průmyslu a obchodu bude plnit funkci kontaktního místa a současně bude příslušné $\mathrm{k}$ prověřování zahraničních investic a $\mathrm{k}$ rozhodování o jejich povolení. $V$ prípadě, kdy zahraniční investice bude představovat ohrožení bezpečnosti České republiky nebo jejího vnitřního pořádku, bude konečné rozhodnutí o ní svěřeno vládě. ${ }^{17}$ Zahraniční investoři budou povinni dodržovat povinnosti vyplývající ze zákona od 1. 5. 2021, kdy nabývá účinnosti.

\section{POUŽITÉ PRAMENY}

Commission Staff Working Document on Foreign Direct Investment in the EU 13. 3. 2019 (SWD (2019) 108).

${ }^{17}$ Před vydáním sborníku byl dne 19. 1. 2021 přijat zákon č. 34/2021 Sb., o prověřování zahraničnich investic (pozn. ed.). 
Evropská komise. Diskusní dokument o využití potenciálu globalizace [online]. 10. 5. 2017 [cit. 2019-07-27]. Dostupné z: <https://ec.europa.eu/commission/sites/beta-political/ files/reflection-paper-globalisation_cs.pdf>

Evropská komise. Tisková zpráva: Vstupuje v platnost nařízení EU o prověřování zahraničních investic [online]. 10. 4. 2019 [cit. 2019-07-27]. Dostupné z: <https://ec.europa. eu/commission/presscorner/detail/cs/IP_19_2088>

FECÁK, Tomáš. Mezinárodní dohody o ochraně investic a právo Evropské unie. Praha: Wolters Kluwer, 2015, $548 \mathrm{~s}$. HODER, Lukáš. Nové nařízení EU o prověřování zahraničních investic nabylo platnosti. In: epravo.cz [online]. 30. 5. 2019 [cit. 2019-07-27]. Dostupné z: <https://www.epravo.cz/ top/clanky/nove-narizeni-eu-o-proverovani-zahranicnich -investic-nabylo-platnosti-109430.html>

Návrh nařizení Evropského parlamentu a Rady, kterým se stanoví rámec pro prověřování přímých zahraničních investic do Evropské unie [online]. 13. 9. 2017 [cit. 2019-07-27]. Dostupné z: <https://eur-lex.europa.eu/legal-content/CS/ ALL/?uri=CELEX \%3A52017PC0487>

Návrh zákona o prověřování zahraničních investic [online]. 17. 4. 2019 [cit. 2019-07-27]. Dostupné z: <https://apps. odok.cz/veklep-detail?pid=KORNBBBJBKCC>

Sdělení Komise: Vstřícnost vưči přímým zahraničním investicím a současná ochrana základních zájmů ze dne 19. 9. 2017.

Usnesení Evropského parlamentu ze dne 5. července 2017 o vypracování ambiciózní průmyslové strategie EU jako strategické prioritě pro růst, zaměstnanost a inovace v Evropě (2017/2732(RSP)). 